\title{
35. SKELETAL DEBRIS OF FISHES
}

Phyllis B. Helms and W.R. Riedel, Scripps Institution of Oceanography, University of California, La Jolla, California

It has long been known that fish skeletal debris in the form of bone fragments, shagreen denticles ("placoid scales") and small teeth is present in practically all pelagic sediments-often even in those described as "unfossiliferous" (Murray 1887, 1910; Riedel 1963). Thus, these skeletal fragments offer the only possible basis (aside from spores and pollen) for biostratigraphic interpretation of pelagic sediments lacking calcareous and siliceous microfossils.

One of the authors (P.B.H.) recently has made a preliminary investigation of fish debris in deep-sea sediment cores, with a view to determining their biostratigraphic applicability. The preparations used have been simple Canada Balsam mounts of the fraction of pelagic clays coarser than 62 microns, in some cases concentrated by "panning-off" the lighter particles (siphoning off lighter material while keeping it suspended in water by continuous motion). Recently, our collection of preparations has been significantly augmented by David C. Clegg, who has applied a method using heavy liquids and centrifuging developed by Jerry L. Matthews (personal communication) to concentrate fish debris from dated fossiliferous sediments. This preliminary investigation has provided some understanding of Cenozoic assemblages of fish skeletal debris in Pacific and Indian Ocean sediments.

At one of the drilling sites on Leg 7 (Site 66, at $2^{\circ} 23.63^{\prime} \mathrm{N}, 166^{\circ} 07.28^{\prime} \mathrm{W}$; water depth 5295 meters), a sequence of clays containing no fossils other than fish debris was sampled intermittently between 148 and 187 meters below the sea floor. The next sample above this clay sequence is Middle Tertiary (at about 120 meters below the sea floor), and below it (at about 190 meters) were found Cretaceous radiolarians. It was therefore of interest to see if fish debris can be used to determine whether the otherwise nonfossiliferous clays are Paleogene or Cretaceous.

\section{PACIFIC CENOZOIC FISH DEBRIS}

The most common distinctive forms of fish skeletal debris found in marine sediments are teeth. For this reason we have studied the teeth most intensively, and the following discussion is confined to the teeth and one non-tooth structure. In order to discuss them it is necessary to introduce some morphological and structural terms.
Fish teeth are composed of essentially the same structural elements as are mammalian teeth, that is, enamel (not always present), modified dentine (which functions as does enamel in mammalian teeth), dentine, and a pulp cavity with nutritive tubules passing into the dentine. There is no true root since the teeth of fish are attached directly to the bones of the jaw (Plate 2, Figure 1, included only to illustrate this relationship). The term "base" is used for the root-like structure often found still attached to the tooth proper (Peyer, 1968, p. 14). (Figure 1 A-D, adapted from Dean, 1895, p. 24, fig. 20.) A complete descriptive terminology has not been worked out, but will have to be adapted and extrapolated from previous works on both fish and mammalian teeth.

The characteristics used here to distinguish between forms of fish teeth are, in order of importance: modifications of the shape of the tooth and its relationship to the base, shape and extent of the pulp cavity, and the area covered by modified dentine and/or enamel.

Size is not a consistent factor because fish may have teeth of varying sizes, depending on: (1) the position in the mouth and, (2) the stage of development, not only of the fish itself, but also of the teeth during the various stages of the tooth-replacement process (Peyer, 1968, pp. 40, 44).

Tooth shapes may vary in a single fish according to their function and placement in the mouth (for example, whether in the upper or lower jaw). In addition, the teeth present in marine bottom sediments occur as separate entities, and cannot always be related to genera or species of fish. For these reasons, a system of classification should be used which will not conflict with the Linnaean classification should it ever be possible to relate tooth to fish. Therefore, the Ordo militaris, or "military classification", proposed by Croneis (1938) and based on the classical divisions of the Roman army, will be used eventually. In the present study, however, a temporary system utilizing letters for manipulus (= genus) and numbers for centurion (= species) is deemed sufficient.

Previously studied Pacific Cenozoic fish teeth assemblages were compared with those from the drill cores from Sites 7, 24 and 66. Since only two forms (types $\mathrm{M}$ and $\mathrm{P}-1$, both rare) were found in the Cretaceous 


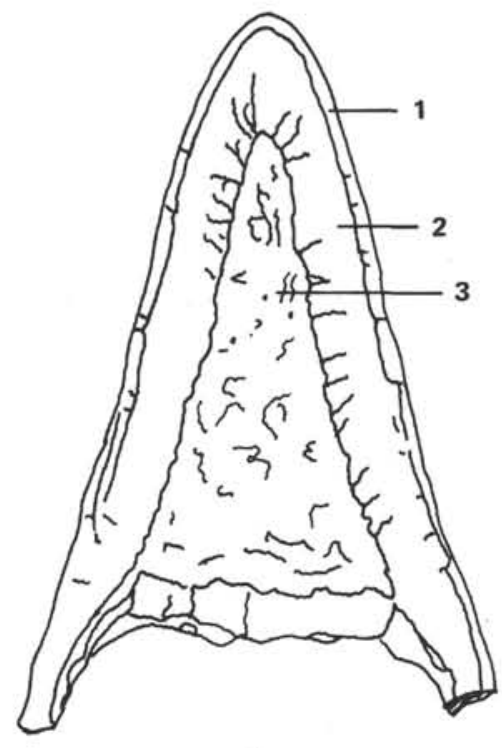

A
1. Enamel or modified dentine

2. Dentine

3. Pulp cavity with nutritive tubules passing into dentine

4. Base

Figure 1. Structural features of fish teeth; $A, B$ and D, X 133; C, X 275 .

Site 24 material, this sample was not included in Table 1. On examining this material, one general feature became immediately obvious. Many of the teeth in these samples exhibit modifications of the basic form that are more complicated, and more frequently involving the entire tooth, than the known Eocene and younger forms. A comparison of Plates 1 and 2 demonstrates this difference.

Plate 1 illustrates a few of the types of teeth found in Pacific Cenozoic sediments. Some of these forms appear to be stratigraphically significant:

Type A (Plate 1, Figures 1 and 2) has been found in Middle Eocene to Lower Miocene sediments. A-2, showing a broadening nearer the tip than $\mathrm{A}-1$, is the more common of the two. This seems to be one of the few Neogene types (perhaps the only one) which shows modification of the common, simple form in the upper part of the tooth. Most variations of the basic form occur in the lower one-half, and often only the bottom of the tooth is involved (see Plate 1, Figures $5-7$ and $11-15)$.

Type B (Plate 1, Figure 3), with the barb below the tooth (apparently a modification of the base rather than of the tooth proper), may arise in the Lower Eocene; however, insufficient dated material of this age makes the time of this development uncertain. Type B occurs in Middle Eocene and Oligocene sediments, is much more common in the Lower Miocene, and seems to become extinct during or at the beginning of the Upper Miocene. Some centuria may prove to be quite restricted in age, but no serious attempt has been made as yet to divide the group on this level.

Type C-1 (Plate 1, Figure 4), from the uppermost Eocene of the Pacific, appears to be related to type C-2 (Plate 2, Figure 7) from the Site 66 cores, primarily in the relationship of the tooth to its base and the appearance of the base itself with its obvious termination. C-1 has not been found in the Oligocene through Lower Pliocene samples examined, and reappears in the Upper Pliocene, becoming extinct before the Quaternary.

All of the type D forms (Plate 1, Figures 5-7 and 11-15) exhibit the same characteristic narrow tip and broad base, extensive pulp cavity, and simple modifications confined to the lower end of the tooth.

Types D-1 and D-2 (Plate 1, Figures 5 and 6) in which the lower margins of the tooth are smoothly curved inward, occur in the Eocene and range into the Lower Miocene.

Type D-3a (Plate 1, Figure 7) is present in the Eocene and disappears at the top of the Lychnocanium bipes radiolarian zone just above the Oligocene-Miocene boundary. D-3b (Plate 1, Figure 8) arises in this zone, and occurs intermittently through the Spongaster pentas 
TABLE 1

Ages of Fish Teeth

\begin{tabular}{|c|c|c|c|c|c|c|c|c|c|c|c|c|c|c|c|c|c|c|c|c|c|c|c|}
\hline & & & $\overrightarrow{\dot{\alpha}} \stackrel{\sim}{\sim}$ & $\infty$ & $\vec{u}$ & $\dot{0}$ & $\dot{\jmath}$ & $\tilde{a}$ & ஸि & $\hat{n}$ & ڤْ & مُ & जิ & \begin{tabular}{|l|l} 
& $\overrightarrow{0}$ \\
\end{tabular} & 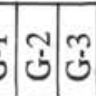 & $\hat{\xi}=$ & & & $\Sigma \bar{z} \mid \tilde{z}$ & $\begin{array}{c}y_{1} \\
\bar{z}\end{array}$ & $\stackrel{2}{2}$ & $\approx$ & Radiolarian Zones \\
\hline \multirow{2}{*}{\multicolumn{2}{|c|}{ 莺 空 }} & JYN V 38PG, 98-101 & & $?$ & & & & & & & & $?$ & & & & & & & & & & & \multirow{2}{*}{ Quaternary } \\
\hline & & PROA 128G, $67-70$ & & & & & & & & & & & & & & & & & & & & & \\
\hline \multirow{4}{*}{ 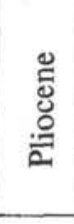 } & \multirow{2}{*}{ 芯. } & AMPH 97P, 422-425 & & & & & & & & $?$ & & & & & & & & & & & & & \multirow{2}{*}{ Pterocanium prismatium } \\
\hline & & AMPH 98P, 500-503 & & & & & & & & & & & & & & & & & & & & & \\
\hline & \multirow{2}{*}{ فํ. } & AMPH 130G, 90-93 & & & & & & & & & & & & & & & & & & & & & Spongaster pentas \\
\hline & & RIS $102 \mathrm{G}, 47-50$ & & $?$ & & & & & & & & & & & & & & & & & & & \multirow{2}{*}{ Stichocorys peregrina } \\
\hline \multirow{10}{*}{$\begin{array}{l}\stackrel{\Xi}{\Xi} \\
\stackrel{\Xi}{\Sigma}\end{array}$} & \multirow{3}{*}{ s.ّ. } & JYN V 38P, 420-423 & & & & & & & & & & & & $?$ & & & & & & & & & \\
\hline & & RIS $102 \mathrm{G}, 83-86$ & & & & & & & & & & & & & & & & & & & & & \multirow{2}{*}{ Ommatartus antepenultimus } \\
\hline & & PROA 102P, 250-253 & & & & & & & & & & & & & & & & & & & & & \\
\hline & \multirow{3}{*}{$\frac{\dddot{\sigma}}{\frac{\pi}{2}}$} & PROA 96P, 297-300 & & & & & & & & & & & & & & & & & & & & & \multirow{2}{*}{ Cannartus (?) petterssoni } \\
\hline & & PROA 97P, 370-373 & & & & & & & & & & & & & & & & & & & & & \\
\hline & & PROA 96P, 480-483 & & & & & & & & & & & & & & & & & & & & & Dorcadospyris alata \\
\hline & \multirow{4}{*}{ ฏ. } & MSN 135P, 70-73 & & & $?$ & & & & & & & & & & & & & & & & & & \multirow{2}{*}{ Calocycletta costata } \\
\hline & & AMPH 109P, 325-328 & & & & & & & & & & & & & & & & & & & & & \\
\hline & & MSN 135P, 702-705 & & & & & $?$ & & & $?$ & & & & & & & & & & & & & Calocycletta virginis \\
\hline & & AMPH 144G & & & & $?$ & & & & & $?$ & & & & & & & & & & & & \multirow{2}{*}{ Lychnocanium bipes } \\
\hline \multirow{2}{*}{ 。윯 } & \multirow{2}{*}{ 悹 } & MSN 149P, 295-298 & & & & & & & & & & & & & & & & & & & & & \\
\hline & & RIS $111 \mathrm{P}, 420-422$ & & & & & & & $?$ & ? & & & & & & & & & & & & & Dorcadospyris ateuchus \\
\hline \multirow{4}{*}{ 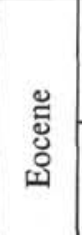 } & \multirow{2}{*}{ 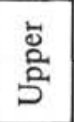 } & LSDH 91P, 550-555 & & & & & & & & & & & & & & & & & & & & & Thyrsocyrtis bromia \\
\hline & & JYN V 10P, 904-929 & & & & & & & & & & & & & & & & & & & & & Thyrsocyrtis tetracantha \\
\hline & \multirow{2}{*}{ 莺 } & LSDH 88P, 353-356 & & & & & & & $?$ & & & & & & & & & & & & & & Podocyrtis mitra \\
\hline & & JYN V 28P, 396-399 & & & & & & & & & & & & $?$ & & & & & & & & & Thyrsocyrtis triacantha \\
\hline
\end{tabular}


$\vec{N}$

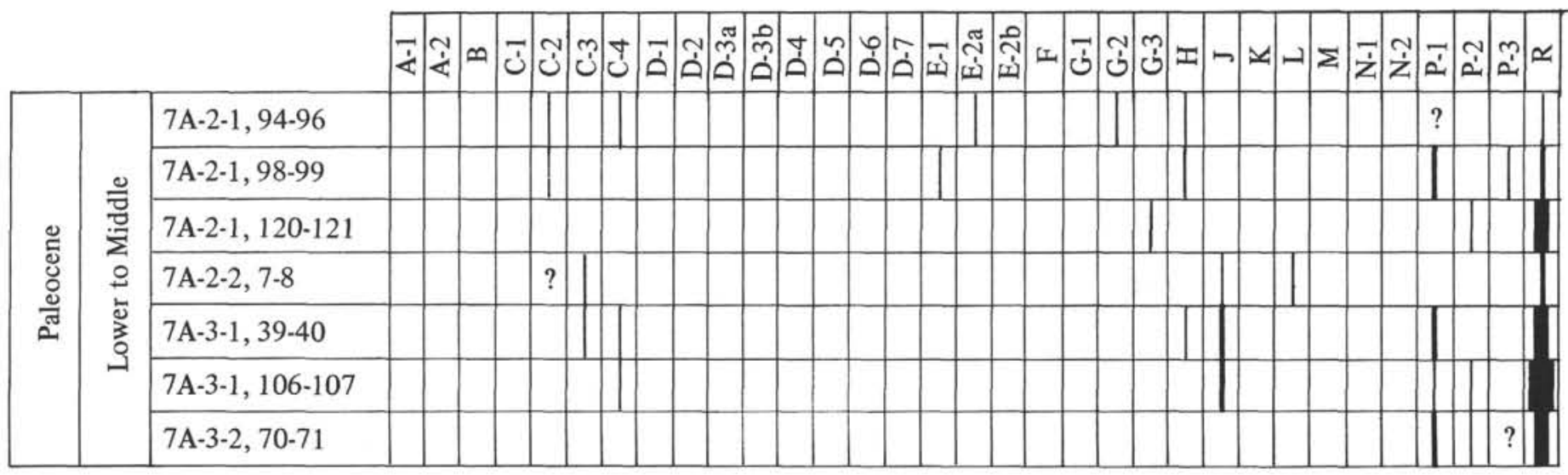

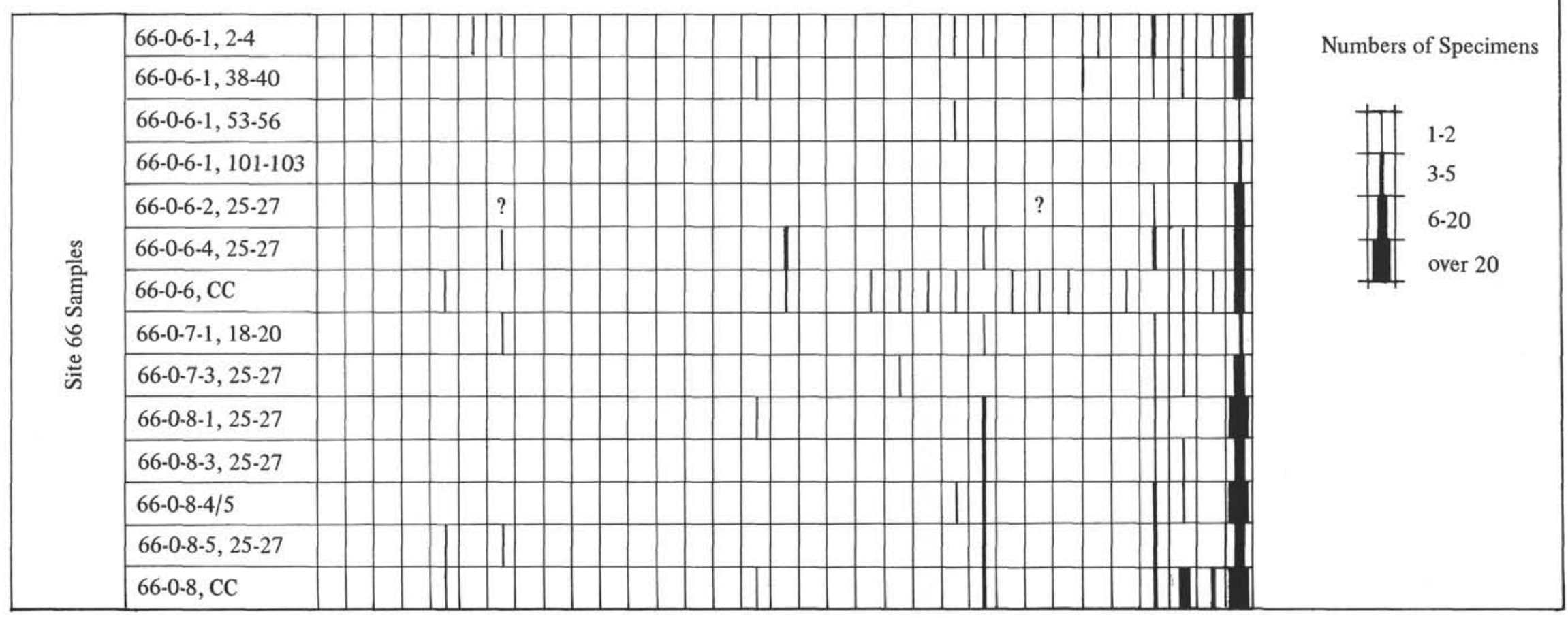


zone of the (approximately) Middle Pliocene. D-3b lacks the obvious distinction between tooth and base seen in D-3a and, unlike D-3a, the edge of modified dentine is continuous along tooth and base. The "canal system" extends farther toward the tip in D-3b. (The two forms may very well be of different centuria, rather than subcenturia, but may certainly be grouped in the same manipulus.)

Type D-5 (Plate 1, Figure 12) has a narrow tip, slightly curved edges, and smooth but abrupt termination on one side, with the other side probably extending along the base which, however, is usually missing so that the irregular broken end is all that is seen. (Compare with D-4, Plate 1, Figure 11, which appears to be complete.) D-5 is rather rare in the Oligocene, relatively common in the Lower to lower Middle Miocene, and is very rare to absent in Upper Miocene and younger assemblages. D-4 may prove to have approximately the same upper limit, but probably arose in the Upper Oligocene or Lower Miocene.

Type D-6 (Plate 1, Figures 13 and 14) differs from type D-7 (Plate 1, Figure 15) in the smoothly rounded narrow edge below the inner angle of the broad, bladelike upper portion. In this section D-7 has a secondary blade, the edge of which blends into the upper section just above the lower edge of the primary blade. D- 6 specimens are rarely as well-preserved as those illustrated in Figures 13 and 14, and are less common than type B but more common than D-5. D-6 is present in Upper Oligocene material, and is relatively common in the Lower Miocene with very rare specimens appearing in Pliocene and Quaternary. Those in the youngest material may be reworked. D-7 ranges from the Lower Miocene (and perhaps earlier) through the Quaternary.

Type E-2b (Plate 1, Figure 9) will be discussed in connection with the Site 66 forms shown in Plate 2, Figures 18 and 19.

Type F (Plate 1, Figure 10), apparently restricted to upper Upper Eocene through about Middle Oligocene, is characterized by a pulp cavity that extends about half way toward the tip and is somewhat constricted at the bottom, with the modified dentine not completely covering the dentine at the constriction, but curving away from the center to the bottom outer edge. A distinct line separates tooth from base, and the tooth is often found alone.

\section{FISH DEBRIS IN THE DRILLED CORES}

\section{A. In Tertiary Cores Containing Other Microfossils}

A preliminary survey of a few assemblages of fish debris in the Eocene, Oligocene and Miocene Leg 7 material indicates that the forms present are like those of the Pacific and Indian ocean cores discussed above. All of the forms illustrated in Plate 1 are present, except that type B is very rare and usually incomplete. Many types not illustrated but frequently encountered in other, widely distributed core material are also present, but the time-ranges of most of these have not yet been established.

\section{B. In Cores 66-0-6, 66-0-7 and 66-0-8 at Site 66}

Many of the teeth present in the otherwise nonfossiliferous clays of Site 66 (Plate 2) differ sufficiently from the known Cenozoic forms as to suggest that these clays are Paleocene or older. In fact, with the exception of types C-2 (Plate 2, Figure 7), C-3 (Plate 2, Figure 13), C-4 (Plate 2, Figure 14), and E (Plate 2, Figures 18 and 19), and the unspecified form in Plate 2, Figure 1, these forms have not been found elsewhere except in material from Leg 1 (7A-2-1, 7A-2-2, 7A-3-1 and 7A-3-2) which has been dated as Lower Paleocene by means of benthonic foraminifera (E.C. Milow, personal communication).

One form found at Site 66 (type E) ranges from at least Lower Paleocene (E-1, Plate 2, Figure 18) to approximately middle Tertiary (E-2b, Plate 1, Figure 9), but most of the other illustrated forms are more restricted in time. Type $\mathrm{C}$ is present in Paleocene through upper Tertiary material, but $\mathrm{C}-1$ seems to be the only centurion occurring above the Oligocene.

Type G (Plate 2, Figures 2, 3 and 4), with spiral or subspiral ridges, and with small knobs on the tip in G-2 and G-3, has been found only in the Paleocene samples.

Type $\mathrm{H}$ (Plate 2, Figure 5) is known only from the Paleocene. A simple description, such as "tip pointed with a barb on one side of the base", would suggest a relationship to type B (Plate 1, Figure 3). However, there is no distinction between tooth and base as in type B. The only point of similarity is the barb, and the two do not seem to be closely related.

Type J (Plate 2, Figure 6), with a shallowly bifurcated grooved tip, a small knob just below the tip, and a pulp cavity which terminates below the knob, is present in the Paleocene material but not higher.

Types K, L and N (Plate 2, Figures 8, 9, 11 and 12) seem to be restricted to the Paleocene. Of the three, $\mathrm{K}$ and $\mathrm{N}$, with their distinctive "wings", were found in Site 66 material but not in the dated Site 7A material. Type M (Plate 2, Figure 10) with its multiplaned surface, has representatives on the manipulus level in the Cretaceous (24A-1-1, Light), and probably into the late Tertiary since a few specimens of the same general configuration have been noted in post-Paleocene material.

Type $P$ (Plate 2, Figures 15, 16 and 17), with the thin flange-like edges of modified dentine that extend around the tip, is present in both the Cretaceous 


\section{APPENDIX \\ LOCATIONS OF SAMPLES STUDIED}

AMPH 97P,

AMPH 98P,

AMPH 109P,

AMPH 130G,

AMPH 144G,

JYN V 10P,

JYN V 28P,

JYN V 38PG \& P,

LSDH 88P,

LSDH 91P,

MSN 135P,

MSN 149P,

PROA 96P,

PROA 97P,

PROA 102P,

PROA 128G,

RIS 102G,

RIS $111 \mathrm{P}$,

Site 7 ,

Site 24 ,

Site 66, $3^{\circ} 42^{\prime} \mathrm{S}, 157^{\circ} 40^{\prime} \mathrm{W}$,

$2^{\circ} 50^{\prime} \mathrm{S}, 157^{\circ} 13^{\prime} \mathrm{W}$,

$4^{\circ} 49^{\prime} \mathrm{S}, 155^{\circ} 19^{\prime} \mathrm{W}$,

$5^{\circ} 58^{\prime} \mathrm{S}, 142^{\circ} 43^{\prime} \mathrm{W}$,

$11^{\circ} 42^{\prime} \mathrm{N}, 131^{\circ} 38^{\prime} \mathrm{W}$,

$12^{\circ} 43^{\prime} \mathrm{N}, 152^{\circ} 06^{\prime} \mathrm{W}$,

$14^{\circ} 13^{\prime} \mathrm{N}, 146^{\circ} 24^{\prime} \mathrm{W}$,

$6^{\circ} 30^{\prime} \mathrm{N}, 141^{\circ} 59^{\prime} \mathrm{W}$,

$8^{\circ} 33^{\prime} \mathrm{N}, 177^{\circ} 46^{\prime} \mathrm{W}$,

$9^{\circ} 11^{\prime} \mathrm{N}, 172^{\circ} 03^{\prime} \mathrm{W}$,

$4^{\circ} 26^{\prime} \mathrm{S}, 149^{\circ} 24^{\prime} \mathrm{W}$,

$9^{\circ} 23^{\prime} \mathrm{N}, 145^{\circ} 15^{\prime} \mathrm{W}$,

$5^{\circ} 12^{\prime} \mathrm{N}, 177^{\circ} 43^{\prime} \mathrm{E}$,

$4^{\circ} 32^{\prime} \mathrm{N}, 179^{\circ} 45^{\prime} \mathrm{E}$,

$4^{\circ} 58^{\prime} \mathrm{N}, 177^{\circ} 33^{\prime} \mathrm{W}$,

$0^{\circ} 09^{\prime} \mathrm{S}, 162^{\circ} 56^{\prime} \mathrm{W}$,

$6^{\circ} 23^{\prime} \mathrm{S}, 136^{\circ} 11^{\prime} \mathrm{W}$,

$14^{\circ} 55^{\prime} \mathrm{N}, 133^{\circ} 29^{\prime} \mathrm{W}$,

$30^{\circ} 08.04^{\prime} \mathrm{N}, 68^{\circ} 17.80^{\prime} \mathrm{W}$,

$6^{\circ} 16.58^{\prime} \mathrm{S}, 30^{\circ} 53.46^{\prime} \mathrm{W}$,

$2^{\circ} 23.63^{\prime} \mathrm{N}, 166^{\circ} 07.28^{\prime} \mathrm{W}$, water depth $5228 \mathrm{~m}$.

water depth $5225 \mathrm{~m}$.

water depth $5265 \mathrm{~m}$.

water depth $4450 \mathrm{~m}$.

water depth $4935 \mathrm{~m}$.

water depth $5549 \mathrm{~m}$.

water depth $4952 \mathrm{~m}$.

water depth $5018 \mathrm{~m}$.

water depth $5620 \mathrm{~m}$.

water depth $5510 \mathrm{~m}$.

water depth $4600 \mathrm{~m}$.

water depth $5100 \mathrm{~m}$.

water depth $5828 \mathrm{~m}$.

water depth $5712 \mathrm{~m}$.

water depth $5399 \mathrm{~m}$.

water depth $5180 \mathrm{~m}$.

water depth $4410 \mathrm{~m}$.

water depth $4770 \mathrm{~m}$.

water depth $5185 \mathrm{~m}$.

water depth $5148 \mathrm{~m}$.

water depth $5293 \mathrm{~m}$.

\section{EXPLANATION OF PLATES}

In the figure explanations the designations in the form "(U35/1)" indicate England Finder positions of the illustrated specimens on the slides, determined with the slide label on the right. The England finder label is always to the microscopist's left. 



\section{PLATE 1}

Figure 1

Figure 2

Figure 3

Figure 4

Figure 5

Figure 6

Figure 7

Figure 8

Figure 9

Figure 10

Figure 11

Figure 12

Figures 13, 14 Type D-6, 13; MSN 135P, $702-705 \mathrm{~cm}$, Slide C, (G26/4-H26/2) 105X: 14; AMPH 97P, 422-425 cm, Slide A, V32/2-V33/1) 125X.

Figure 15

Type $A-1$, JYN V 28P, 396-399 cm, (P55/0-4) 125X.

Type $A-2$, JYN V28P, $396-399 \mathrm{~cm}$, (R-S/36-37) $125 \mathrm{X}$.

Type $B$, LSDH $88 \mathrm{P}, 353-356 \mathrm{~cm}$, Slide B, (W45/0) $215 \times$.

Type $C$ - 1 , LSDH $91 \mathrm{P}, 550-555 \mathrm{~cm}$, Slide A, (F54/03-4) $215 x$.

Type $D-1$, LSDH $91 \mathrm{P}, 550-555 \mathrm{~cm}$, Slide B, (U35/3-4) 40X.

Type $D$-2, LSDH 91P, 550-555 cm, Slide B, (U35/3-4) $53 / 2-1) 65 X$.

Type D-3a, RIS 111P, $420-422 \mathrm{~cm}$, Slide A, (P19/0) $65 \mathrm{x}$.

Type $D-3 b$, AMPH 109P, $325-328 \mathrm{~cm}$, Slide B, (X5758/2-1) $65 \mathrm{X}$.

Type $E$-2b, RIS $111 \mathrm{P}, 419-422 \mathrm{~cm}$, Slide D, (L23/0) $105 X$.

Type $F$, RIS 111P, $419-422 \mathrm{~cm}$, Slide D, (T39/1) $105 \mathrm{X}$.

Type D-4, AMPH 144G, Slide A, (N60/4) 65X. Type D-5, MSN 135P, 702-705 cm, Slide D, (E62/4F62/2) 105X.

Type D-7, AMPH 109P, 325-328 cm, Slide A, (Y39/0) 65X. 
PLATE 1

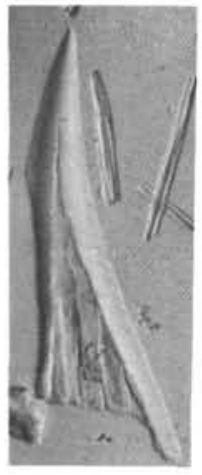

1
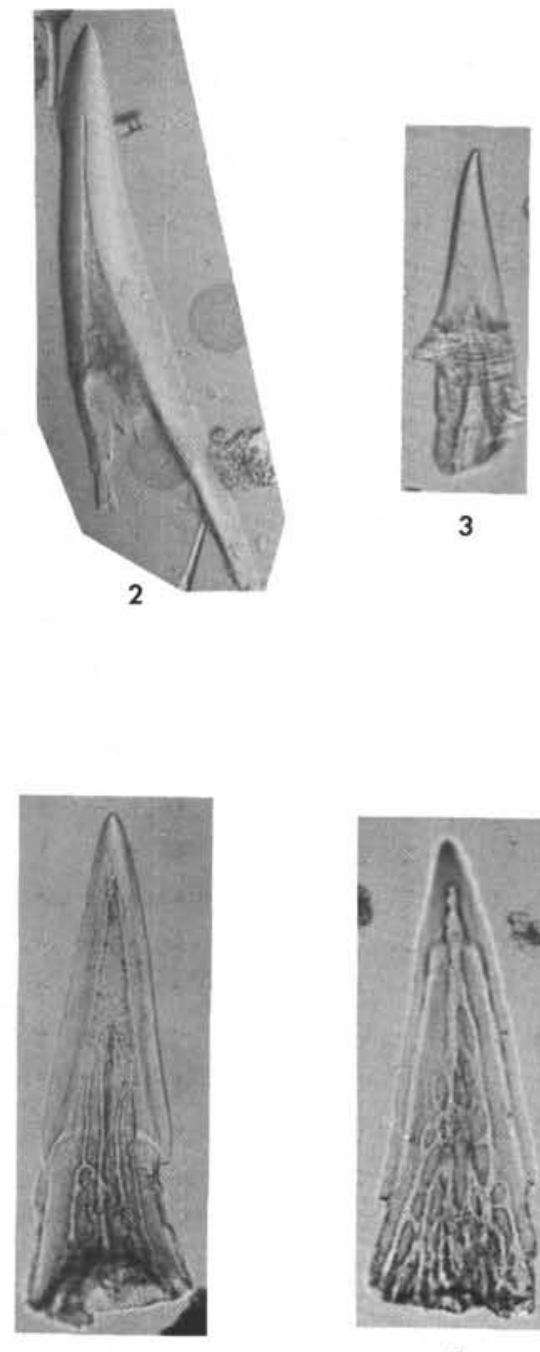

7

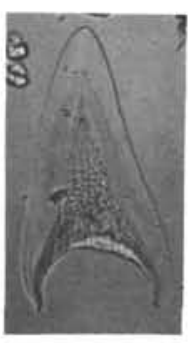

6

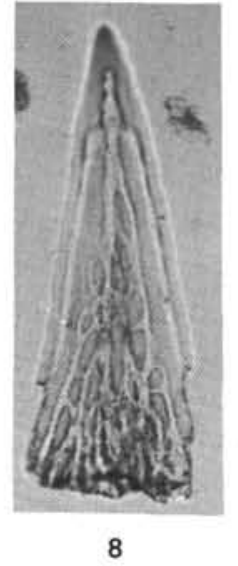

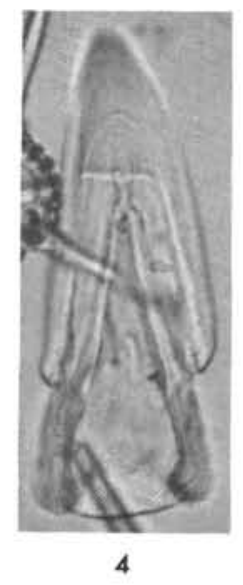

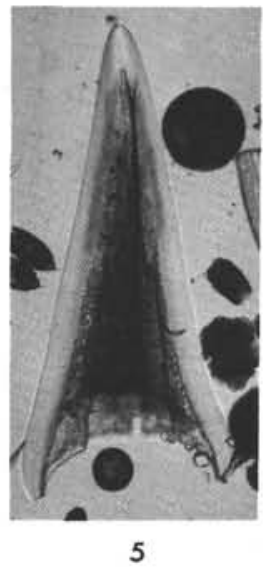

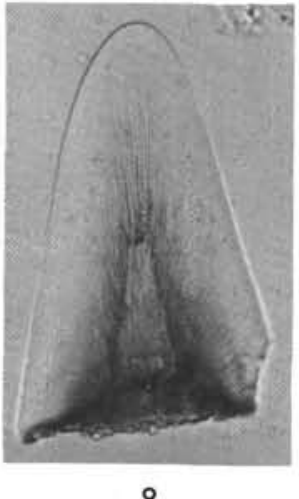
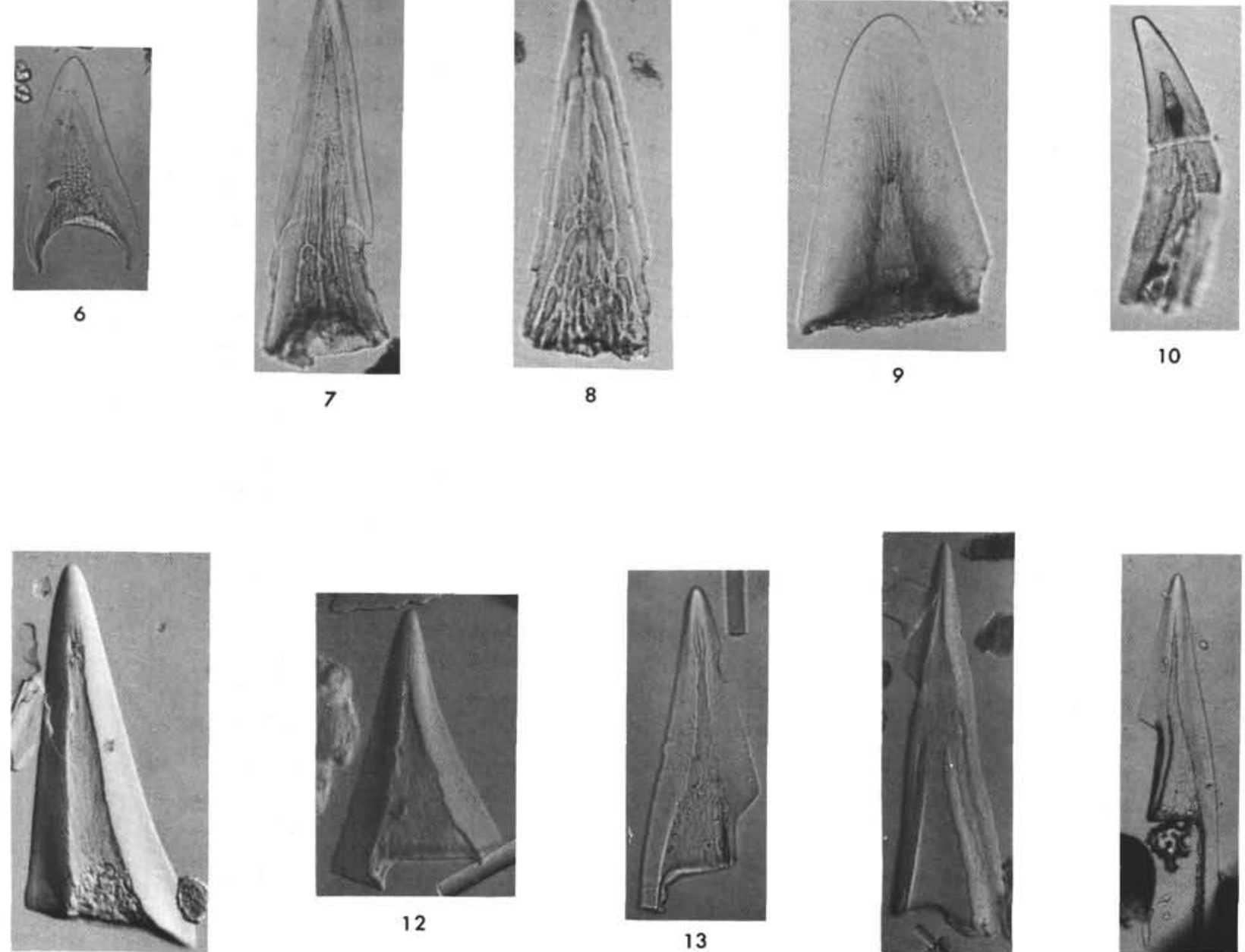

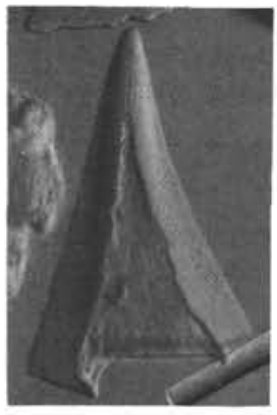

12

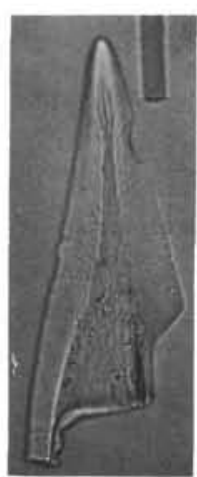

13

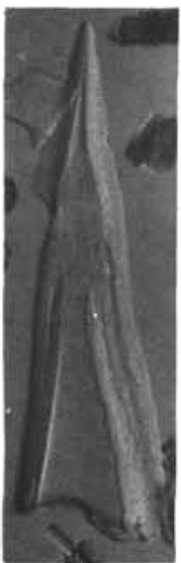

14

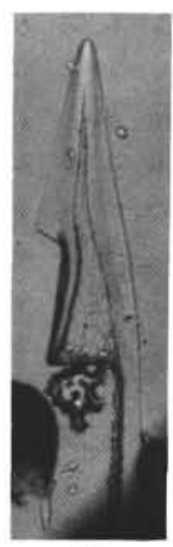

15 
PLATE 2

(Magnifications: All 190X except Figures 7 and 19, 115X)

\begin{tabular}{|c|c|}
\hline & Teeth \\
\hline Figure 1 & 66.0-6-CC. \\
\hline Figure 2 & Type G-1, 66.0-6-CC, Slide 2 (J52/4-J53/3). \\
\hline Figure 3 & Type $G-2,66.0-6-C C$, Slide 2 (E51/1). \\
\hline Figure 4 & Type $G-3,66.0-6-\mathrm{CC}$, Slide 2 (K50/2). \\
\hline Figure 5 & Type $H, 66.0-6-1,53-56 \mathrm{~cm}(\mathrm{M} 28 / 4)$. \\
\hline Figure 6 & Type $J, 66.0-8$-CC, Slide 3 (B45/4). \\
\hline Figure 7 & Type $C-2,66.0-6-C C$, Slide 2 (X57/3). \\
\hline Figure 8 & Type $K, 66.0-6-C C$, Slide 2 (R40/4). \\
\hline Figure 9 & Type $L, 66.0-6-C C$, Slide $2(B 43 / 0)$. \\
\hline Figure 10 & Type $M, 66.0-6-\mathrm{CC}$, Slide 1 (R42/1). \\
\hline Figure 11 & Type $N-1,66.0-6-1,2-4 \mathrm{~cm}(\mathrm{G} 51 / 0)$. \\
\hline Figure 12 & Type $N-2,66.0-6-\mathrm{CC}$, Slide $2(\mathrm{~K} 55 / 0)$ \\
\hline Figure 13 & Type $C-3,66.0-6-1,2-4 \mathrm{~cm}(\mathrm{M} 50 / 0)$ \\
\hline Figure 14 & Type $C-4,66.0-6-4,25-27 \mathrm{~cm}(\mathrm{~S} 62 / 1)$ \\
\hline Figure 15 & Type $P-1,66.0-6-1,2-4 \mathrm{~cm}(\mathrm{M} 51 / 1)$. \\
\hline Figure 16 & Type $P$-2, 66.0-6-CC, Slide $2(\mathrm{R} 43 / 0)$. \\
\hline Figure 17 & Type $P-3,66.0-6-\mathrm{CC}$, Slide $2(028 / 2)$. \\
\hline Figure 18 & Type $E-1,66.0-8$-CC, Slide $3(\mathrm{C} 32 / 3)$. \\
\hline \multirow[t]{2}{*}{ Figure 19} & Type $E-2 a, 66.0-6-4,25-27 \mathrm{~cm}(037 / 1-3)$. \\
\hline & Rings (R) \\
\hline Figure 20 & 66.0-6-CC, Slide 2 (W30/1). \\
\hline Figure 21 & 66.0-6-CC, Slide 1 (P36/3). \\
\hline Figure 22 & 66.0-6-CC, Slide 2 (V59/0). \\
\hline Figure 23 & 66.0-6-CC, Slide 2 (V59/0[1-2]). \\
\hline Figure 24 & 66.0-6-CC, Slide 2 (X51/4). \\
\hline Figure 25 & $66.0-6-4,25-27 \mathrm{~cm}(\mathrm{R} 23 / 2)$ \\
\hline
\end{tabular}


PLATE 2

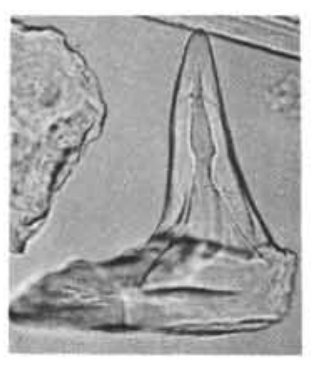

1
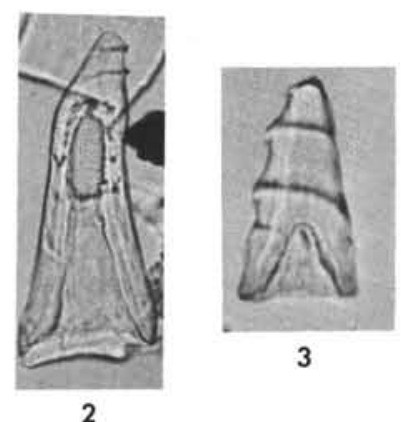

2
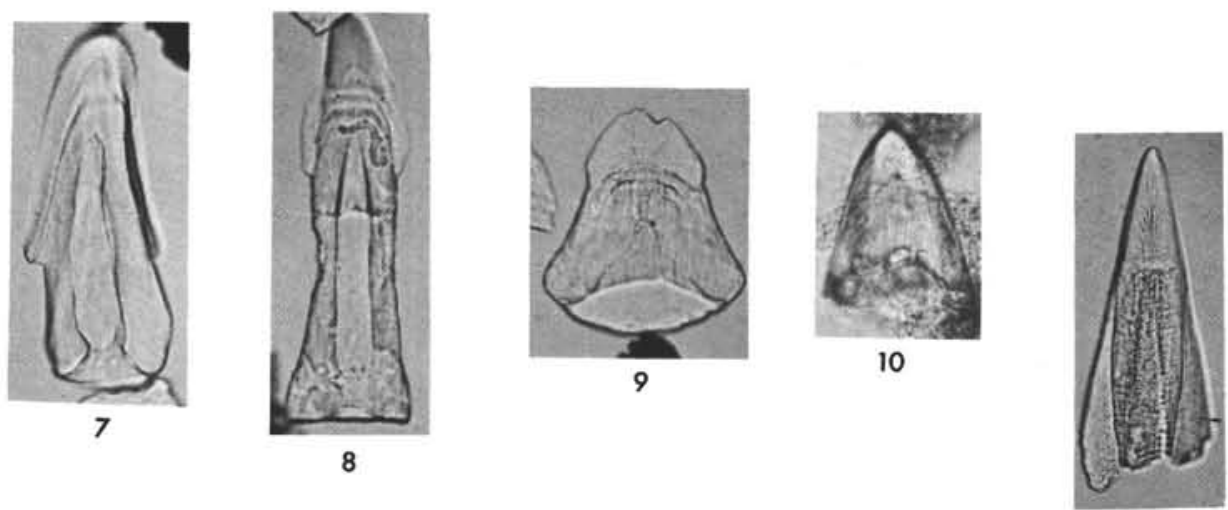

11
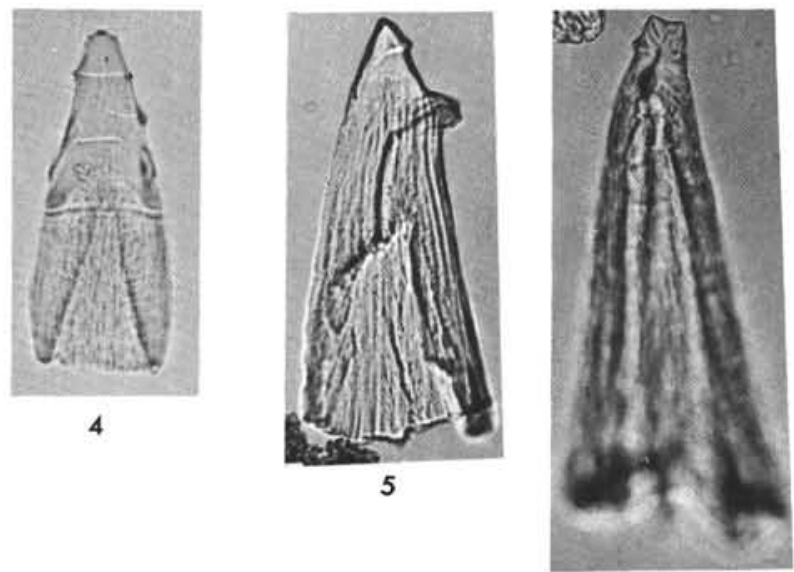

6

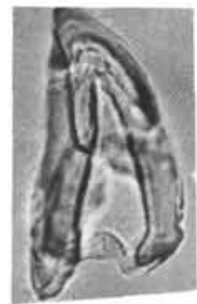

13
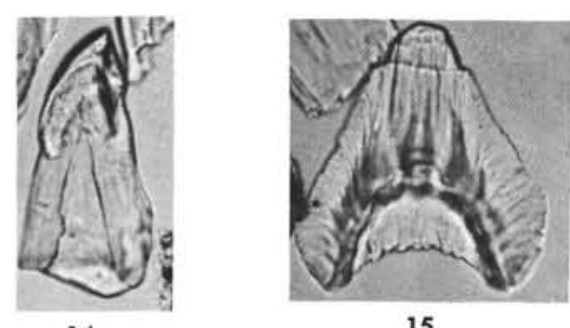

15
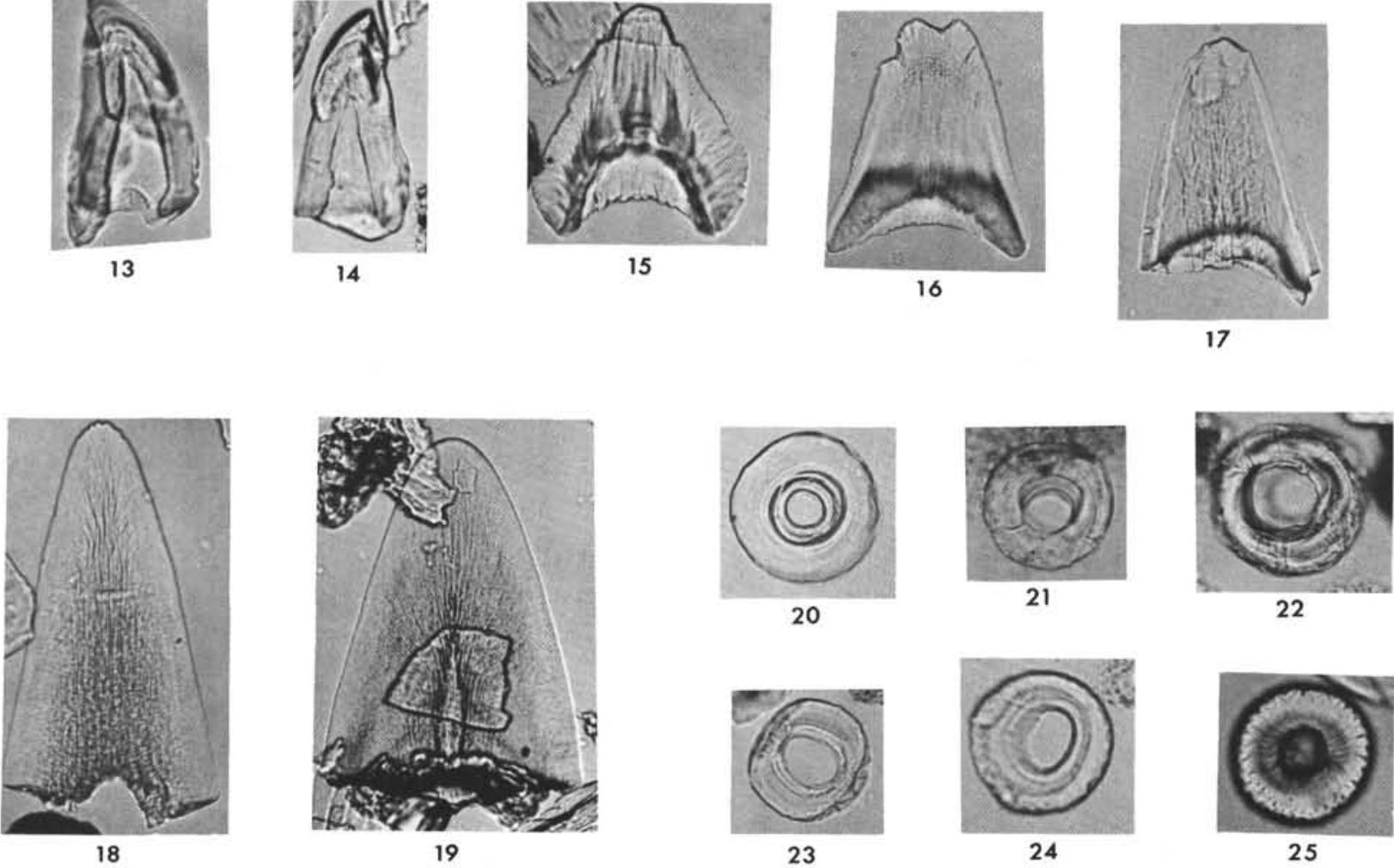

23

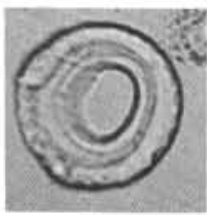

24

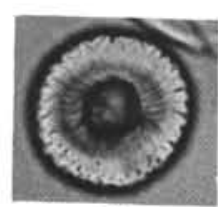

25 
(24A-1-1, Light) and Paleocene. If there are representatives in younger material, as there may well be, the characteristic thin edge is no longer quite so prominent.

Another and very strong indication of a pre-Eocene age for the Site 66 clays is the presence in relatively large numbers of the ring-like form illustrated in Figures 20 through 25 on Plate 2. No structure at all like this has been seen in Eocene or younger core material, but a large number of individuals has been found in one of the Paleocene samples examined from Leg 1 (7A-3-1, 106 to 107 centimeters), with significant numbers also occurring in other Leg 1 samples (7A-2-1, 120 to 121 centimeters, 7A-2-2, 7 to 8 centimeters, and $7 \mathrm{~A}-3-2,70$ to 71 centimeters).

\section{POTENTIAL STRATIGRAPHIC APPLICABILITY}

The preliminary results reported here indicate that the ubiquitous fish skeletal debris, especially the teeth, are a potentially useful tool for biostratigraphic interpretation of pelagic clays lacking calcareous and siliceous microfossils. In fact, one of the writers (P.B.H.) has already made such use of some of the forms discussed herein on pre-drilling site surveys with satisfactory results.

Table 1 (for sample locations, see appendix) shows that some forms of fish teeth seem to have rather well-defined age-ranges, at least in tropical deep-sea sediments, and that assemblages are different in different parts of the Cenozoic. Also, the fish skeletal debris from Site 66, when compared with known Tertiary examples, provides strong evidence that the otherwise nonfossiliferous clays there are at least as old as Paleocene, and the fact that they are underlain by a probably Turonian-Cenomanian radiolarian assemblage means that they probably are not older than Upper Cretaceous.

\section{ACKNOWLEDGEMENTS}

The authors wish to thank Frances L. Parker for the many helpful suggestions during the course of this investigation, and for her critical reading of the manuscript. E. Dean Milow, Deep Sea Drilling Project, and Robert G. Douglas, Case Western Reserve University, kindly examined the foraminifera from the Leg 1 samples to determine ages for control purposes.

This research was supported principally by the U.S. Office of Naval Research (contract Nonr-N00014-69A-0200-6006); Deep Sea Drilling Project samples were provided by the National Science Foundation, the agency that also supported the expeditions on which many of the Scripps Institution of Oceanography cores were collected.

\section{REFERENCES}

Croneis, Carey, 1938. Utilitarian classification for fragmentary fossils. J. Geol. 46 (7), 975.

Dean, Bashford, 1895. Fishes, Living and Fossil. New York (McMillan and Co.) $300 \mathrm{pp}$.

Murray, John, 1885. Reports on the specimens of bottom deposits. Museum Comp. Zool., Bull. 12 (2), 37.

1889. On marine deposits in the Indian, Southern, and Antarctic oceans. Scot. Geog. Mag. August 1889, 1-32, 1 chart.

1902. Deep-sea deposits and their distribution in the Pacific Ocean. Geogr. J. June 1902, 1-21, 1 chart.

1906. On the depth, temperature of the ocean waters, and marine deposits of the South Pacific Ocean. Roy. Geogr. Soc. Australia. Queensland, 71-134, 1 chart, 1 table.

1910. The deep sea. Scot. Geogr. Mag. Dec. 1910, 617-624, 2 figs., 2 pls.

Peyer, Bernhard, 1968. Comparative Odontology. Rainer Zangerl (Ed.). Chicago (U. of Chicago Press) 347 pp., $88+8$ pls.

Riedel, W.R., 1963. Paleontology of pelagic sediments. In The Sea. M.N. Hill (Ed.). New York (Interscience) 3,866 . 